\title{
ISSR marker based DNA profiling studies in Rauwolfia species
}

Gulab Khan Rohela1, 3*, Prasad Bylla ${ }^{1}$, Sreenu Pendli², Korra Rajender ${ }^{2}$ and

Christopher ReubenThammidala ${ }^{2}$

${ }^{1}$ Department of Biotechnology, Kakatiya University, Warangal- 506 009, Telangana, INDIA.

${ }^{2}$ Department of Botany, Kakatiya University, Warangal- 506 009, Telangana, INDIA.

3Biotechnology Section, Moriculture Division, Central Sericultural Research \& Training Institute, Central Silk Board, Ministry of Textiles, Government of India, Pampore -192 121, Jammu and Kashmir, INDIA.

Received: 3/28/2018; Revised: 4/13/2018; Accepted: 4/30/2018

\begin{abstract}
In this present study, a protocol was developed for the DNA profiling of medicinally important Rauwolfia species (05 species) by ISSR-PCR method. Initially genomic DNA was isolated from the fresh leaves (1 gram) of 24 months old Rawnolfia tetraphylla, R.serpentina, R.pentaphylla, R.vomitaria and R.micrantha. The content of genomic DNA isolated from 1 gram of fresh leaves of these five species ranges from 1.6 to $3.4 \mu \mathrm{g}$. Out of six inter simple sequence repeats (ISSR) primers used, HY3 primer has given the good amplification with distinct bands which were reproducible. The range of DNA bands produced by the HY3 primer were between $300 \mathrm{bp}$ to $1500 \mathrm{bp}$ among the five species. A dendrogram was constructed on the basis of similarity matrix data by unweighted pair group method with arithmetic average (UPGMA) cluster analysis using indigenous software. Average genetic similarity generated by HY3 has revealed 38\% similarity between species of Sub cluster-A and species of Sub cluster-B which is consistent with their geographical distribution i.e. Sub cluster-A species R.tetraphylla and R.serpentina inhabit peninsular India, Sub cluster- B species R.micrantha and R. vomitoria inhabit the Himalayan foot hills. The developed protocol of DNA profiling in Raunolfia species by ISSR-PCR method could be used efficiently for the differentiation and identification of the Ramwolfia species at molecular level.
\end{abstract}

Key words: Rauwolfia, DNA Profiling, ISSR-PCR, Dendrogram Analysis

\section{Introduction}

In the Apocynaceae family among the 250 genera, the genus Rauwolfia is commonly called as snake weed which possess more than 100 species and most of them has lot of medicinal importance due to their traditional use in Indian system of Ayurveda. The genus Ramwolfia was named in honour of the German physician Dr Leonhard Rauwolf, who studied several plant species of this genus, while travelling in India (Douglas, 2015). Ramwolfia genus has gained lot of importance after the Indian physician Vakil introduced it to the Western countries where he used roots of Rauwolfia serpentina for the successful treatment of several patients who were suffering with high blood pressure (Vakil, 1949).

Among the different species of Rauwolfia, five species (Rauwolfia serpentina, R.tetraphylla R.petaphylla, R.vomitoria and R.micrantha) were exploited more due to the presence of commercially important alkaloids such as ajmalicine, ajmaline, deserpidine, isoreserpiline, reserpine, reserpine, reserpiline, raujemidine, serpentine, tetraphylline, sarpagine, vellosimine and yohimbines (Mukherjee, 1961). It is well known that R.serpentina is native to India (Vakil, 1949), while all the remaining four species are exotic

\footnotetext{
*Corresponding Author:

Gulab Khan Rohela,

Biotechnology Section, Moriculture Division,

Central Sericultural Research \& Training Institute,

Central Silk Board, Ministry of Textiles,

Government of India, Pampore -192 121,

Jammu and Kashmir, India.

E-mail: gulab_biotech@yahoo.co.in
}

flora, which are now naturalized in most parts of India (Panda et al., 2012). These five species of snake root plants are now found growing in Indian States like: Andhra Pradesh, Telangana, Tamil Nadu, Kerala, Karnataka, Maharastra, Orissa, Chhattisgarh, Madhya Pradesh, and West Bengal (Singh et al., 1990).

There are several reports about the in vitro micropropagation (Sudha et al.,1996; Faisal et al.,2012; Rohela et al.,2015; Sonibare and Akpan, 2017), secondary metabolites (Shetty et al., 2014; Srivastava et al., 2016), phytochemical screening (Sarika et al., 2012; Rohela et al., 2016), endophytic organisms (Nath et al., 2015), hairy root cultures (Madhusudanan et al., 2008; Menrotra et al., 2013 \& 2015); quantitative determination of indole alkaloids (Srivastava et al., 2006); antimicrobial activities (Sarika et al., 2012; Rohela et al., 2015) and pharmacological activities (Bilal et al., 2012; Ezeigbo et al., 2012) from this five species. But there is scanty information available on studying the variability among these species.

Variability among these species can be studied at morphological level like plant height, type of leaf, flower colour, fruit type and seed characteristics 
similar at biochemical level type and quantity of phytoconstituents are routinely used to distinguish the Rauwolfia species. However, these methods were not suitable for the accurate identification of a species, as many discrepancies like locality of plant, influence of environment on trait phenotype, gene interactions will act in changing the characteristic of a species at morphological and biochemical level.

In the modern era of technology, genetic diversity among the related species of a genus can be assessed accurately at molecular level by carrying out DNA profiling using molecular markers like SSR, ISSR, SNP's, RAPD and AFLP which is reported in several genera like Vicia (Megahed et al., 2015), Solanum (Hong et al., 2014), Rheum (Wang et al., 2012), Capsicum (Prasad et al., 2013), Luffa (Yamuna Prasad et al., 2017; Sujatha et al., 2013) etc. These molecular markers are more efficient than phenotypic and biochemical markers and the technique is simple, low cost and does not use radioactive probes (Sitthiwong et al., 2005).

To the best of our knowledge, until now as there are no reports on genetic diversity studies in Rauwolfia species, now through this research study we are reporting for the first time about the Genetic diversity among the Rauwolfia species through the ISSR-PCR method based method of DNA profiling.

\section{Materials and Methods}

Plant Material: Rauwolfia species vi\%. Rauwolfia tetraphylla, R.serpentina, R.pentaphylla, R.vomitaria and R.micrantha were procured from Forest Department, Warangal, Telangana, India in January, 2009. They were maintained in the medicinal arboretum of the Department of Biotechnology, Kakatiya University, Warangal, Telangana and were used in the present investigation.

Isolation of plant genomic DNA using C-TAB method: Genomic DNA was isolated fromfresh leaves of 24 months old Rauwolfia tetraphylla, R.serpentina, R.pentaphylla, R.vomitaria and R.micrantha by following the protocol of Doyle and Doyle, (1990). The method is as follows.

a. Fresh leaves (1 gram) of five species of Rawwolfia was grounded into a fine paste using $500 \mu$ l of C-TAB buffer.

b. Leaf extract was transferred to eppendorf tubes and incubated for about 15 minutes at $55^{\circ} \mathrm{C}$ in a dry bath.

c. After incubation, the leaf extract was centrifuged at $12000 \mathrm{rpm}$ for $5 \mathrm{~min}$, to pellet out cell debris and to the supernatant $250 \mu \mathrm{l}$ of Chloroform: Iso-amyl alcohol (24:1) was added and mixed by repeatedly inverting the tube.

d. After proper mixing, the eppendorf tubes were centrifuged at $13000 \mathrm{rpm}$ for $1 \mathrm{~min}$. e. Upper aqueous layer (containing DNA) was transferred to a clean eppendorf tube, to which $50 \mu \mathrm{l}$ of $7.5 \mathrm{M}$ ammonium acetate and $500 \mu \mathrm{l}$ of ice-cold absolute ethanol/ iso propanol were added and inverted slowly for several times to precipitate the isolated DNA.

f. To further purify, the precipitated DNA was washed with $500 \mu \mathrm{l}$ of ice-cold $70 \%$ ethanol for several times.

g. Final centrifugation was carried at $13000 \mathrm{rpm}$ for 1 minute, supernatant was removed and the DNA pellet was air dried.

h. The DNA pellet was dissolved in 1X TE buffer and DNA quantification was performed using Spectrophotometer to determine the concentration and purity of DNA samples.

i. Pure DNA of $20 \mu \mathrm{l}(25 \mathrm{ng})$ was used in PCR experiment.

\section{Quantification and Quality analysis of isolated DNA}

To quantify the amount of DNA isolated from the 1 Gram of Leaf sample of 5 Ranwolfia species, we have used the spectrophotometer measurements of the amount of ultraviolet irradiation absorbed by the bases at 260 and $280 \mathrm{~nm}$ (Korra et al., 2017).

\section{DNA quality checks}

DNA quality check was made through a test gel run to know whether the isolated DNA is in degraded or undegraded state. Intact, undigested DNA forms a band, where as a smear indicates degradation (longer the smear, more is the extent of degradation). Slight degradation sometimes may not be detected, while a highly degraded DNA may appears as a diffuse spots near the end of the gel.

\section{ISSR-PCR Analysis}

ISSR analysis was performed as per the method of William's et al., (1990) by using ISSR primers (Table-1). PCR mixture was prepared using the following quantities of chemicals given in Table- 2 and the amplification was carried out in a thermocycler (Gene Amp PCR system 9700, Applied Biosystems, California, USA), the programming conditions are given in Table-3.

To reduce the possibility of cross contamination in amplification reaction, a master reaction mixture was routinely prepared and a negative control was also be used; this control consisted of PCR reaction mixture excluding DNA template. Amplification was performed at least twice and only reproducible amplified PCR products were separated on 1.5\% Agarose gel.

\section{Agarose Gel Electrophoresis (AGE)}

The Agarose gel electrophoresis was performed by the following steps.

a. Agarose was dissolved in $1 \mathrm{X}$ TAE buffer by heating in microwave oven. 
b. Molted Agarose was cooled to $55^{\circ} \mathrm{C}$ and $5 \mu \mathrm{l}$ of Ethidium bromide was added to it.

c. Forty (40) $\mathrm{ml}$ of Agarose solution was poured into a gel tray and a comb was inserted at one end and left for gel formation.

d. The comb was removed from the gel to form wells.

e. Agarose gel tray was inserted into Electrophoretic unit containing $1 \mathrm{X}$ buffer.

f. One tenth $(1 / 10)$ volume of dye was added to $10 \mu \mathrm{l}$ DNA sample.

g. In the first well $10 \mu \mathrm{l}$ of molecular marker (0.5$10 \mathrm{~Kb}$ ) was added and $10 \mu \mathrm{l}$ DNA sample was loaded into other wells, using micropipette.

h. The Electrophoretic unit was connected to the power supply and the gel was run for 45 minutes with 80 volts of current

i. Finally the power supply was terminated and the gel tray was removed from the unit and viewed under gel documentation system.

\section{Dendrogram Analysis}

A Dendrogram was constructed on the basis of similarity matrix data by unweighted pair group method with arithmetic average (UPGMA) cluster analysis using indigenous software by the method described by Sitthiwong et al., 2005. Data generated in ISSR analysis by the method of Nei et al., 1979, which excludes negative data on this equation. Similarity $=2 \mathrm{~N}_{\mathrm{ab}} /\left(\mathrm{N}_{\mathrm{a}}+\mathrm{N}_{\mathrm{b}}\right)$, where $\mathrm{N}_{\mathrm{a}}=$ number of scored amplified fragments in genotype a and $\mathrm{N}_{b}$ $=$ number of scored amplified fragments in genotype $\mathrm{b}$ and $\mathrm{N}_{\mathrm{ab}}=$ number of scored amplified fragments with the same molecular weight shared between genotypes A and B.

\section{Results and Discussion}

The amount of genomic DNA isolated from the leaves of 24 months old Rawwolfia species viz: R.tetraphylla, R.serpentina, R.pentaphylla, R.micrantha and R.vomitoria is presented in Fig-1.The content of genomic DNA in these five species ranges from 1.6 to $3.4 \mu \mathrm{g}$ in 1 gram of fresh leaves which was estimated by spectrophotometer.

The number of bands produced by the HY3 primer ranged between 300 bp to 1500 bp (Table-4). Rauwolfia tetrapbylla, R.pentaphylla \& R.vomitoria produced 5 bands, while R.serpentina produced 4 bands and R.micrantha produced 3 bands (Fig-2). A DNA band admeasuring $0.7 \mathrm{~kb}$ was observed in all 5 species and DNA band admeasuring $0.9 \mathrm{~kb}$ was observed in 4 species.

Dendrogram analysis showed that 5 species of Rauwolfia are grouped into two main clusters; Cluster-A and Cluster-B (Fig-3). Cluster-A has single species R.pentaphylla and Cluster-B includes R.tetraphylla, R.serpentina, R.micrantha and R.vomitoria. Cluster-B has two Sub clusters, Sub cluster-A and Sub cluster-B. Sub cluster-A comprises of
R.tetraphylla \& R.serpentina and Sub cluster-B comprises of R.micrantha \& R. vomitoria.

The genomic DNA isolated from R.tetraphylla, R.serpentina, R.pentaphylla, R.micrantha and R.vomitoria ranged between 1.6 to $3.4 \mu \mathrm{g}$. Gurudeeban et al., (2011), also isolated 1.5-2.5 $\mu \mathrm{g}$ of DNA from Suaeda sp of Apocynaceae family. The ISSR genetic profile obtained through amplification of genomic DNA of five Rauwolfia species was polymorphic. Mahesh et al., (2008), using RAPD markers analyzed Ramwolfia tetraphylla plants collected from five locations of thiruvinelli hills in Tamil Nadu, India and reported that there is distinct genetic variability. Similar studies were undertaken in Arachis hypogea (Raina et al., 2001); Morus alba (Srivastava et al., 2004); Capsicum annuum (Sitthiwong et al., 2005); Chimonanthus praecox (Zhao et al., 2007); Catharanthus roseus (Pietrosiuk et al., 2007); Dioscorea opposite (Zhou et al., 2008); Hyptis (Kranthi et al., 2011); Artemisia capillaries (Shafie et al., 2011); Rheum officinale (Wang et al., 2012); Bacopa monnieri (Tripati et al., 2012) and Ocimum sp (Sanjay et al., 2012).

RAPD and ISSR markers are very simple, rapid and reliable; they require a small quantity of DNA sample and knowledge regarding DNA sequence to design primers is not necessary. They do not use radioactive probes as in RFLP; hence they are suitable for assessment of genetic fidelity of in vitro raised clones.

Among the different Rauwolfia species, RAPD and ISSR markers were used for confirming genetic fidelity of tissue culture plantlets of R.tetraphylla and R.serpentina (Spiridonova et al., 2008; Goel et al., 2009; Tiwari et al., 2011; Faisal et al., 2012 a, 2012 b; Alatar et al., 2012; Rohela et al., 2013). Mehrotra et al., (2012), has reported about genetic fidelity of tissue culture plantlets of Rawwolfia vomitoria by using ISSR and RAPD markers.

Except for confirming the genetic fidelity of in vitro regenerated plantlets of R.serpentina, R.tetraphylla and R.micrantha, there is scanty information on the application of molecular markers for studying genetic variability of Rauwolfia species growing in wild (in vivo).

Average genetic similarity generated by $\mathrm{HY} 3$ has revealed $38 \%$ similarity between species of Sub cluster-A and species of Sub cluster-B which is consistent with their geographical distribution i.e. Sub cluster-A species R.tetraphylla and R.serpentina inhabit peninsular India (Anitha and Kumari, 2007), Sub cluster- B species R.micrantha and R. vomitoria inhabit the Himalayan foot hills (Prajapati et al., 2003; Heber et al., 2006). India. It is well known that R.serpentina is native to India (Vakil 1949), while all the remaining four species are exotic flora, which are now naturalized in most parts of India (Panda et al., 2012). 
Table 1. List of ISSR primers

\begin{tabular}{cc}
\hline S.NO & ISSR-Primers \\
\hline 1 & HY1: 5'- TCTCTCTCTCTCTCTCTC - 3' \\
2 & HY2: 5'- GAGAGAGAGAGAGAGAC - 3' \\
3 & HY3: 5'-AGAGAGAGAGAGAGG - 3' \\
4 & HY4: 5'- GAGAGAGAGAGAGAGAT- 3' \\
5 & HY5: 5'- CGACGACGACGACGACGA- 3' \\
6 & HY6: 5'- TGCTGCTGCTGCTGCTGCTGC- 3' \\
\hline
\end{tabular}

Table 2. PCR Mixture

\begin{tabular}{|c|c|c|}
\hline S.No & Chemical & Quantity \\
\hline 1 & 25 ng of genomic DNA & $2.0 \mu \mathrm{l}$ \\
\hline 2 & 2.5mm dNTPs & $2.0 \mu \mathrm{l}$ \\
\hline 3 & $\begin{array}{l}\text { Taq buffer }(100 \mathrm{mM} \text { Tris hydrogen } \\
\text { chloride }, \mathrm{pH} 8.3,500 \mathrm{mM} \\
\begin{array}{l}\text { Potassium } \\
\text { gelatin })\end{array}\end{array}$ & $2.0 \mu \mathrm{l}$ \\
\hline 4 & 25mM Magnesium chloride & $2.0 \mu \mathrm{l}$ \\
\hline 5 & ISSR primer (Bioserve) & $3.0 \mu \mathrm{l}$ \\
\hline 6 & 0.5 unit of Taq DNA polymerase & $1.0 \mu \mathrm{l}$ \\
\hline \multirow[t]{2}{*}{7} & $\begin{array}{l}\text { Autoclaved Milli Q water (PCR- } \\
\text { grade water) }\end{array}$ & $8.0 \mu \mathrm{l}$ \\
\hline & Total & $20.0 \mu \mathrm{l}$ \\
\hline
\end{tabular}

Table 3. Thermocycler programming conditions used in the study

\begin{tabular}{lccc}
\multicolumn{1}{c}{ Steps } & $\begin{array}{c}\text { Temp } \\
\left({ }^{\mathbf{O}} \mathbf{C}\right)\end{array}$ & $\begin{array}{c}\text { Duration } \\
(\mathbf{m i n} .)\end{array}$ & $\begin{array}{c}\text { Cycles } \\
(\mathbf{N o .})\end{array}$ \\
\hline Initial & 94 & 5.0 & 1.0 \\
denaturation & & 1.0 & 35.0 \\
Denaturation & 94 & 1.0 & 35.0 \\
Annealing & 50 & 2.0 & 35.0 \\
Extension & 72 & 10.0 & 1.0 \\
Final extension & 72 & & \\
\hline
\end{tabular}

Table 4. Number and size of DNA bands (kb) generated during HY3-ISSR based PCR analysis in five species of Rauwolfia

\begin{tabular}{clcl}
\hline S.No & $\begin{array}{l}\text { Rauwolfia } \\
\text { species }\end{array}$ & $\begin{array}{l}\text { Number } \\
\text { of bands }\end{array}$ & Size of bands $\mathbf{( K b )}$ \\
\hline 1 & R.tetraphylla & 5 & $0.4,0.5,0.6,0.7,0.9$ \\
2 & R.serpentina & 4 & $0.5,0.6,0.7,0.9$ \\
3 & R.pentaphylla & 5 & $0.6,0.7,0.9,1.5,2.2$ \\
4 & R.micrantha & 3 & $0.4,0.5,0.7$ \\
5 & R.vomitoria & 5 & $0.3,0.4,0.7,0.9,1.3$ \\
\hline
\end{tabular}

Figure 1. Quantity of genomic DNA isolated from 1-gram leaf tissue of 24 months old Rauwolfia plants (5 species)

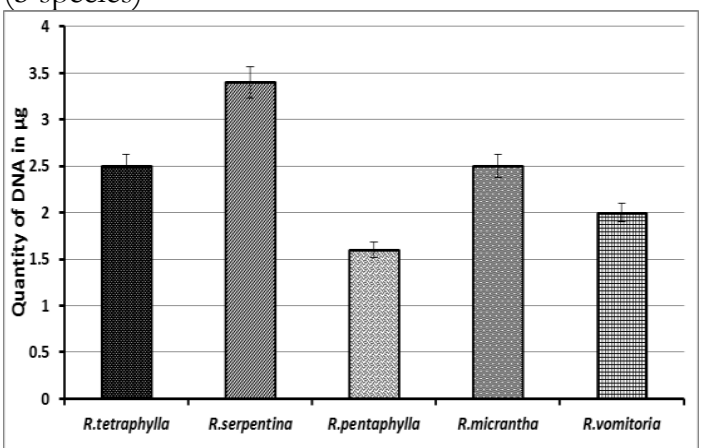

Figure 2. HY3-ISSR primer based DNA profiling in Rauwolfia species

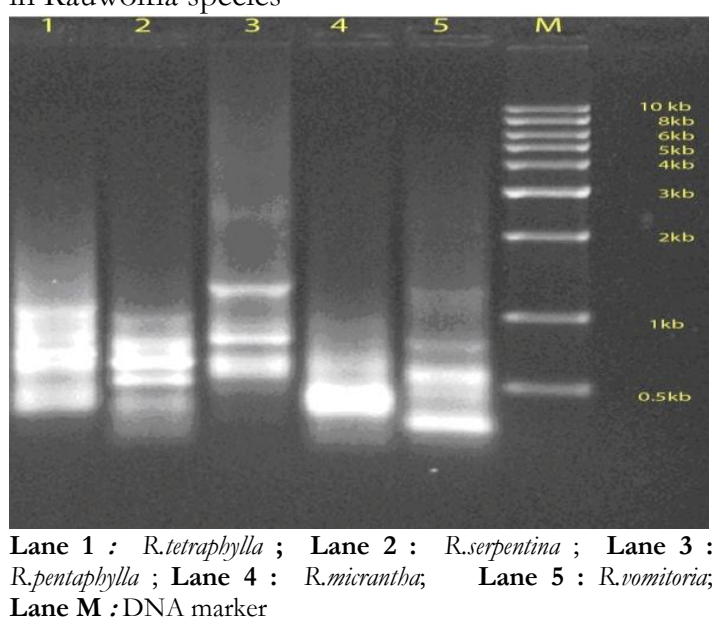

Figure 3. UPGMA dendrogram of 05 Rauwolfia species based on Jaccard similarity coefficients converted from HY3-ISSR marker data.

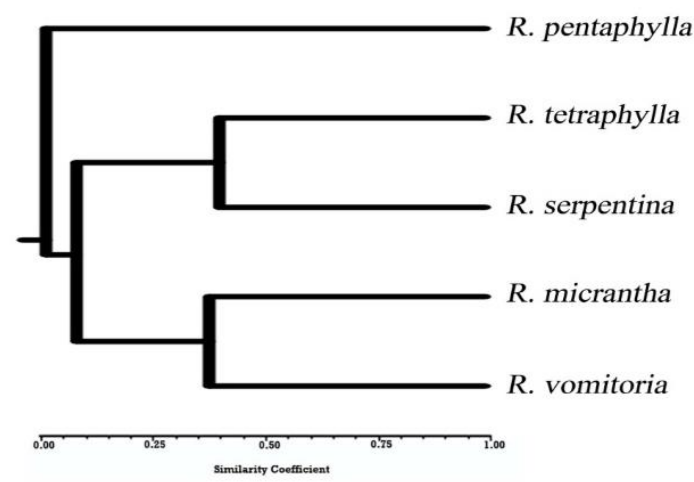

\section{Conclusion}

Among the different ISSR primers used, HY3-ISSR has generated reproducible polymorphism with distinct DNA bands among the five Rauwolfia species which has enabled their identification at molecular level. The developed protocol of DNA profiling in Rauwolfia species by HY3-ISSR-PCR method could be used efficiently by the researchers for the differentiation and identification of 5 mentioned species at molecular level.

\section{Acknowledgement}

Authors thank University Grants Commission, New Delhi, India for providing financial assistance for this research work. Authors also thanks Head, Department of Botany and Head, Department of Biotechnology, Kakatiya University for providing necessary facilities for carrying out the research work.

\section{References}

1. Alatar A and Faisal M. "Encapsulation of Rawvolfia tetraphylla microshoots as artificial seeds and evaluation of genetic fidelity using RAPD and ISSR markers". Journal of Medicinal Plants Research 6(2012):1367-1374. 
2. Anitha S and B D Kumari."Influence of auxins combinations on accumulation of reserpine in the callus of Rawvolfia tetraphylla L". Pakistan Journal of Biological Sciences 10(2007): 3900-3904.

3. Bilal M A, A Q Shamim."Methanolic Root Extract of Rauwolfia serpentina Benth Improves the Glycemic, Antiatherogenic, and Cardioprotective Indices in Alloxan-Induced Diabetic Mice". Advances in Pharmacological Sciences Article ID 376429(2012). http://dx.doi.org/10.1155/2012/376429.

4. Douglas L. "Rauwolfia in the Treatment of Hypertension". Integr Med (Encinitas). 14(2015):4046. PMCID: PMC4566472.

5. Doyle J J and J L Doyle. "A rapid DNA isolation procedure for small quantities of fresh leaf tissue". Phytochemical Bulletin 19(1990):11-15.

6. Ezeigbo I I, M I Ezeja, K G Madubuike, D C Ifenkwe DC, I A Ukweni, $\mathrm{N}$ E Udeh and S C Akomas. "Antidiarrhoeal activity of leaf methanolic extract of Raunolfia serpentina". Asian Pacific Journal of Tropical Biomedicine 2(2012): 430-432. http://dx.doi.org/10.1016/S2221-1691(12)60070-7. PMID: 23569944

7. Faisal M, A A Alatar, N Ahmed, M Anis and K H Ahmed KH. "Assessment of Genetic fidelity in Rauwolfia serpentina plantlets grown from synthetic (encapsulated) seeds following in vitro storage at $4^{\circ} \mathrm{C}^{\prime}$. Molecules 17(2012a): 5050-5061

8. Faisal M, A A Alatar, N Ahmad, M Anis and A K Hegazy. "An Efficient and Reproducible Method for in vitro Clonal Multiplication of Rauvolfia tetraphylla L. and Evaluation of Genetic Stability using DNABased Markers". Appl Biochem Biotechnol 168(2012b):1739-17352.

https://doi.org/10.1007/s12010-012-9893-3.

9. Goel MK, S Mehrotra, A K Kukreja, K Shanker and $\mathrm{S}$ P Khanuja. "In vitro propagation of Ramwolfia serpentina using liquid medium, assessment of genetic fidelity of micro propagated plants, and simultaneous quantitation of reserpine, ajmaline, and ajmalicine". Methods Molecular Biology 547(2009):1733.

10. Gurudeeban S, T Ramanathan, K Satyavani and K Dhinesh. "Standardization of DNA Isolation and PCR Protocol for RAPD Analysis of Suaeda sp". Asian Journal of Biotechnology 3(2011): 486-492.

11. Heber W Y. "Malabar Rauwolfia, Ramwolfia micrantha Hook. F". Journal of the American Pharmacentical Association 43(2006):141-143.

12. Hong $\mathrm{L}$ and G Huachun. "Using SSR to Evaluate the Genetic Diversity of Potato Cultivars from Yunnan Province (SW China)". Acta Biol Cracov Ser Bot 56 (2014):16-27.

13. Kranthi G, U Pavan, A Mahender, R Srinivasa, K Venugopal Rao, $\mathrm{K}$ Kiranmayee and A Sadanandam."Micropropagation of a valuable ethno medicinal plant Streblus asper". Journal of Phytology 3(2011):18-23.

14. Korra R, Bylla P, G K Rohela, S Pendli and T C Reuben. In vitro micro propagation and confirmation of genetic fidelity using RAPD marker in ethno medicinal plant Stachytarpheta jamaicensis L. Vahl. Intern Journal of Advanced Research. 5(2017), 14941502. http://dx.doi.org/10.21474/IJAR01/4862.

15. Madhusudanan K P, S Banerjee, S P Khanuja and S K Chattopadhyay. "Analysis of hairy root culture of Rauvolfia serpentina using direct analysis in real time mass spectrometric technique". Biomed Chromatography 22(2008):596-600.

16. Mahesh R, N Nirmal Kumar and R Mary Sujin. "Molecular Analysis in Rauvolfia tetraphylla L. using RAPD Markers". Ethnobotanical Leaflets 12(2008): 1129-36.

17. Megahed H A, S A Salem, M M Hussein, A K Muhammad, $\mathrm{H}$ E Ehab and A A Sulieman. "Assessment of genetic diversity among faba bean genotypes using agro-morphological and molecular markers".Saudi Journal of Biological Sciences 22(2015):340-350. https://doi.org/10.1016/j.sjbs.2015.02.005.

18. Mehrotra S, M K Goel, L U Rahman and A Kukreja. "Molecular and chemical characterization of plants regenerated from Ri-mediated hairy root cultures of Ramwolfia serpentina". Plant Cell Tissue \& Organ Culture 114(2013):31-8.

19. Mehrotra S, M K Goel, V Srivastava and L U Rahman. "Hairy root biotechnology of Ramwolfia serpentina: A potent approach for the production of pharmaceutically important terpenoid indole alkaloids". Biotechnology Letters 37(2015):253-63.

20. Mehrotra S, L U Rahman, J Mishra, and A K Kukreja. "Conservation and multiplication of encapsulated micro shoots of Rauvolfia vomitoria--an endangered medicinal tree: ISSR and RAPD based evaluation of genetic fidelity of converted plantlets". Natural Products Communication 7(2012):1647-1650.

21. Mukherjee A J. "Alkaloids of Ramwolfia canescens". J. Indian chem Soc 18(1961):33-35.

22. Nath A, A Chattopadhyay and S R Joshi. "Biological activity of endophytic fungi of Ramwolfia serpentina Benth: An ethnomedicinal plant used in folk medicines in Northeast India". Proc National Academic Sciences, India, Sect B Biological Sciences. 85(2015):233-240.

http://dx.doi.org/10.1007/s40011-013-0184-8.

23. Nei $\mathrm{M}$ and W H Li. "Mathematical model for studying genetic variation in terms of restriction endonucleases". Proceedings of National Academic Sciences, USA. 76(1979):5269.

24. Niraj T, S C Devender and S Navinder. "Assessment of genetic variations among highly endangered medicinal plant Bacopa monnieri (L.) from Central India using RAPD and ISSR analysis". 
3Biotech 2(2012):327-336. doi: 10.1007/s13205-0120059-3

25. Panda S K, D Debajoyti, N Bichitra and L N Tripathy. "Phyto-pharmacognostical studies and quantitative determination of reserpine in different parts of Ramwolfia (Spp) of Eastern Odisha by UV Spectrocsopy Method". Asian Journal of Plant Sciences and Research 2(2012):151-162.

26. Pietrosiuk A, M Furmanowa and B Lata. "Catharanthus roseus: micropropagation and in vitro techniques”. Phytochemistry Reviews 6(2007): 459-473.

27. Prajapathi N D, S S Purohit, A K Sharmam, and T Kumarmm. "A handbook of medicinal plants". (Jodhpur: Agrobios)(2013).

28. Prasad B, K R Gulab, T Radha, C H Ravi, P Venkataiah, K Subhash, T R Christopher. "DNA profiling of commercial chilli pepper (Capsicum annum L.) varieties using random amplified polymorphic DNA (RAPD) markers". African Journal of Biotechnology 12 (2013): 4730-4735.

29. Raina SN, V Rani and Kojima. "RAPD and ISSR fingerprints as useful genetic markers for analysis of genetic diversity, variety identification and phylogenetic relationships in parent (Arachis hypogea) accessions \& wild species". Genome 44(2001):763772.

30. Rohela G K, P Bylla, R Korra, C Reuben."Phytochemical screening and antimicrobial activity of leaf, stem, root and their callus extracts in Raunolfia tetraphylla". International Journal of Agriculture \& Biology 18(2016a):521-528. doi: $10.17957 / \mathrm{IJAB} / 15.0120$

31. Rohela G K, B Prasad, C H Ravi, K Rajender, R T Christopher. "In vitro clonal propagation of Rauwolfia tetraphylla, a relative of indian snake root plant”. Research Journal of Biotechnology 11(2015): 23-31.

32. Rohela G K, B Prasad, K Srinivas, A Sadanandam, C $\mathrm{H}$ Ravi, R T Christopher. "In vitro Plantlet Regeneration from Leaf and Stem Calluses of Raunolfia tetraphylla (R. canescens) and Confirmation of Genetic Fidelity of Plantlets Using the ISSR-PCR Method". Journal of Herbs, Spices \& Medicinal Plants 19(2013):66-75.

33. Sanjay L, N M Kinnari, T Riddhi, D S Smit and B V Parth. " Genetic Diversity assessment in six medicinally important species of Ocimum from central Gujarat (India) utilizing RAPD, ISSR and SSR Markers". International Journal of Advanced Biological Research 2(2012): 279-288.

34. Sarika R D, S A Dhanashree, A P Bhausaheb. "Extraction and evaluation of indole alkaloids from Raunolfia serpentina for their antimicrobial and anti proliferative activities". International Journal of Pharmacy and Pharmaceutical Sciences 5(2012):329-334.

35. Shafie M, B Shafie, M Sayed, H Zain, M Z Abdullah and M S Ramisah. "RAPD and ISSR markers for comparative analysis of genetic diversity in wormwood capillary (Artemisia capillaris) from Negeri Sembilan, Malaysia". Journal of Medicinal Plants Research 5(2011):4426-4437.

36. Shetty M R, G A Harisha, Y Jayanth, A H Kumar. "Production of secondary metabolites from in vitro cultures of Rawwolfia serpentina (L.) Benth". International Journal of Science, Technology \& Research 2(2014): 844-852.

37. Singh D K, B Srivastava and A Sahu. "Spectrophotometric determination of Rauwolfia alkaloids: estimation of reserpine in pharmaceuticals”. Anal Science 20(2004): 571-73.

38. Sitthiwong K, T Mastui, S Sukprakarn, N Okuda and Kosugi. "Classification of pepper (Capsicum annum L.) accessions by RAPD analysis". Biotechnology 4(2005):305.

39. Sonibare M A and G U Akpan GU. "In vitro Callus Induction and Antioxidant Activity of Ramwolfia vomitoria Afzel. (Apocynaceae)". Nigerian Journal of Pharmaceutical Research 12(2016):105-115.

40. Spiridonova E V, D M Adnof, I O Andreev and VA Kunakh. "Dynamics of genome changes in Ramwolfia serpentina callus tissue upon the switch to conditions of submerged cultivation". Tsitol 42(2008):35-41.

41. Srivastava A, A K Tripathi, R Pandey, R K Verma and M M Gupta. "Quantitative determination of reserpine, ajmaline, and ajmalicine in Rauvolfia serpentina by reversed-phase high-performance liquid chromatography". Journal of Chromatographical Science 44(2006):557-60

42. Srivastava P P, K Vijayan, A K Awasthi, B Sarat Chandra. "Genetic analysis of Morus alba through RAPD \& ISSR markers". Indian Journal of Biotechnology 3(2004): 527-532.

43. Sudha G G and S Seeni S. "In vitro propagation of Rauwolfia micrantha, a rare medicinal plant. Plant Cell, Tissue and Organ Culture. 44(1996): 243. https://doi.org/10.1007/BF00048530

44. Sujatha D, C H Ravi, L Raghuvardhan, B Prasad, K R Gulab, A Sadanandam and R T Christopher. "In vitro plantlet regeneration and genetic transformation of sponge gourd (Luffa cylindrica L.)". African Journal of Plant Sciences 7(2013):244-252. doi: 10.5897/AJPS12.196.

45. Tiwari K L, S K Jadhav and A Kumar. "Random amplified polymorphic DNA (RAPD) molecular marker based genetic relationship study of medicinal plants collected from tribal region of Chhattisgarh, India”. Research Journal of Biotechnology 6(2011):63-66.

46. Vakil R J. "A clinical trial of Ramwolfia serpentina in essential hypertension. Br Heart J 9(1949):350.

47. Wang X M, X Q Hou, Y Q Zhang, R Yang, S F Feng and Y Li. "Genetic diversity of the endemic and medicinally important plant Rheum officinale as revealed by Inter-Simpe Sequence Repeat (ISSR) 
Markers". International Journal of Molecular Science 13(2012):3900-3915. doi: 10.3390/ijms13033900.

48. Williams J G, A R Kubelik, K J Livak, J A Rafalski and $\mathrm{S} V$ Tingey. "DNA polymorphisms amplified by arbitrarily primers are useful as genetic markers". Nucleic Acids Research 18(1990):6531-6535.

49. Wong K F and R M Taha. "The effect of 2,4Dichlorophenoxyacetic acid and 6benzylaminopurine on callus induction and plantlet regeneration from Allamanda catharitica: A valuable medicinal plant". Research Journal of Biotechnology 7(2002):75

50. Yamuna Prasad S, V B Singh, K S Praveen, K Vimlesh and P Ram. "Genetic Diversity among Promising Lines and their F1 Progeny of Sponge Gourd [Luffa cylindrica (Roem) L.]". International Journal of Current Microbiology \& Applied Sciences
6(2017):2756-2768.

https://doi.org/10.20546/ijcmas.2017.607.386.

51. Zhao K G, Z Ming-Qin and Q C Long. "Genetic Diversity and Discrimination of Chimonanthus praecox (L.) Link Germplasm Using ISSR and RAPD Markers". Hortiscience 42(2007):1144-1148.

52. Zhou $\mathrm{Y}, \mathrm{Z}$ Chune, $\mathrm{Y}$ Huanling, $\mathrm{L}$ Yanju and $\mathrm{T}$ Rongtao. "Application of ISSR markers in detection of genetic variation among Chinese yam (Dioscorea opposita Thunb) cultivars". Life Science Journal 5(2008):6-12.

\section{Cite this article as:}

Gulab Khan Rohela, Prasad Bylla, Sreenu Pendli, Korra Rajender and Christopher Reuben Thammidala. ISSR marker based DNA profiling studies in Rauwolfia species. Annals of Plant Sciences 7.5 (2018) pp. 2289-2295. do $\mathrm{http}: / /$ dx.doi.org/10.21746/aps.2018.7.5.13

Source of support: U.G.C., New Delhi, India.

Conflict of interest: Nil 